\title{
Formation of Worldwide in the Young Generation
}

\author{
Fayziyeva Yulduz Yusupovna ${ }^{1}$, Mardiyeva Dilrabo Nuriddinovna ${ }^{2}$, Bozorova Madina Mahmudovna $^{3}$ \\ Teachers of Samarkand State Institute of Architecture and Construction
}

\begin{abstract}
This article summarizes the views of Eastern and Western thinkers on the formation of the worldview of young people, the formation of the development of the scientific worldview. Thus, the formation of the worldview of the younger generation in the age of information technology and the factors that contribute to it are theoretically based.
\end{abstract}

\section{Keywords}

scientific worldview, religious worldview, mythological worldview, philosophical worldview, aesthetic views, knowledge, universal values.

The formation of a scientific worldview in the younger generation has always been the focus of the nation's progressives. In all the systems that mankind has experienced, the educated, intelligent, knowledgeable people of the time have made significant contributions to world science and human culture. Knowledge is the basis of the scientific worldview. Education, of course, begins at a young age. "Knowledge acquired in youth is a pattern carved in stone," says our wise people. An educated person will never disappear from the pages of history, from the hearts of our people. Among them are Ghazali, Beruni, Khorezmi, Naqshbandi, Yassavi, Western scholars I. Kant, F. Hegel, L. Feuerbach, A. Schopenhauer. The greatest scholars and sages have made a great contribution to the development of mankind with their unique works and teachings. Have you devoted your life to science and mastered the science of life while leaving this enlightened world? to the question that I was going without knowing anything. Surprisingly, the science of life is so mysterious and complex that not even the entire human life can comprehend it.
We have said that knowledge is the basis of the scientific worldview, so what is a worldview? What forms does it have?

The worldview is unique to man, and the animal kingdom is alien to other things, objects, and beings. Their worldview consists of a system of scientific, philosophical, political, legal, moral, aesthetic, religious, views and perceptions of people about the world and its change and development. So, a worldview is a set of generalized knowledge about the universe. The more information people have about the things and events around them, the more perfect and thorough their worldview will be. First of all, it should be noted that the scientific worldview is different. Different professions have different worldviews.

A worldview is a system of general views about the world and one's place in it, people's attitudes toward reality and oneself, as well as people's beliefs, ideals, knowledge, and principles of action based on these views. Worldview depends on one's age, life experience, knowledge and ideology. An individual's worldview is closely linked to social relations. A worldview is formed on the basis of a person's proper understanding and 
evaluation of himself and the world. In this sense, the worldview is a subjective reflection of reality in the human mind. There is an individual worldview that is linked to the consciousness of an individual, a social worldview that is linked to the social consciousness of a particular social group, class, class, nation, and society. They complement each other, influence each other, develop each other. Initially, the individual perceives the world emotionally (feeling the world). In this case, the individual perceives reality as a direct result of emotional perception. Then the individual's worldview emerges on the basis of the knowledge he has gained about reality. This is called understanding the world. A person's self-awareness is formed through his understanding of the world. In this way, all knowledge about the world is highly generalized and a holistic worldview is formed. The worldview has evolved over the course of human history. The following forms of it can be pointed out: 1. A worldview based on mythology or myth. It arose at a time when mythological knowledge of reality was being collected and systematized, and was an imaginary reflection of being in the human mind, unique to the ancients. They described reality on the basis of various legends and myths, and knew it as images that reflected heroes, evil, and good forces. By animating inanimate objects in nature, fire, water, air, and natural phenomena were also considered to be manifestations of certain living images. 2 . Religious worldview. He connects the causes of events in the universe with divine, supernatural powers. Religious beliefs, feelings, beliefs, and the worship of divine powers are important aspects of the religious worldview. 3. The (daily) worldview associated with marriage. It contains imaginative ideas, simple traditional views of the universe and man. 4. Philosophical worldview. It perceives the most general aspects of the whole being, nature, society, human psyche and thinking, on the basis of which a generalized theoretical model of the universe is created. The philosophical worldview relies on other forms of worldview, trying to understand the general laws, aspects in them.

Worldviews form a holistic generalized knowledge of the world, a set of ideas that evaluate them based on the goals of specific social groups, classes, political parties, mass movements, states, and, accordingly, their place in life, areas of practical activity, is a multifaceted and meaningful concept that allows you to define your goals.

There are two levels of worldview. The first is the knowledge, ideas, views accumulated on the basis of people's daily practical experience and professional activity, and the second is the set of theoretical knowledge and ideas accumulated through science. The two are inextricably linked and complement each other.

A worldview is a reflection of a social being. It reflects social life and it depends on the social system. The worldview expresses the most general laws of nature, society, and the development of human thought. The ever-changing and evolving worldview is evident in the exchange of its historical forms.[1]

The formation of the scientific worldview of the younger generation, as in all times, is still in the spotlight of the nation's progressives. The worldview is what surrounds us, how it is developed, how man is in nature, how his consciousness came into being and matured, what is the history of the creation of society, how can humanity improve the standard of living, and so on. different views, relationships. Man uses certain scientific knowledge, laws, concepts and ideas in his work. Based on this knowledge, he evaluates the phenomena of nature, society and human thought, interprets them and draws certain conclusions. Everyone wants to know the purpose of life, the meaning of life. This is the social need of man. This need is also characteristic of the student, who, by satisfying this need, begins to acquire knowledge about the world around him, about nature and society. In general, it activates the various needs of the individual, determines their interests, inclinations and needs. Activities aimed 
at satisfying this need help to form the beliefs and attitudes of the individual, the motives of everyday behavior.

It is necessary to conclude from the essence of the worldview, which is a system of views and beliefs, that a scientific worldview can be formed only when there is a certain system in the work of the student and the school in general. The knowledge that is gradually accumulated is passed down from generation to generation in writing. At different times, educated, intelligent, knowledgeable people have made significant contributions to world science and human culture.

By the second half of the 19th century, Turkestan was occupied by Russian colonialists. During this period, chauvinistic policies prevailed, with a low regard for national and spiritual heritage and culture. However, during this period Said Ahmad Siddiqi (Samarkand), Furkat, Muqimi, A. Donish, Avaz Otar oglu, Hamza, Abdulla Avloni (Tashkent), Ibrat, Fitrat, Behbudi, Munavvar qori, Cho ' lpon, qori Niazi, and others wrote many works on child rearing, striving to enlighten the youth.

Ideas about understanding good and evil, harmonious relationships, love, successful careers, material well-being, creative self-awareness. Dreams and dreams, fears and misconceptions. All of this is clearly shaped within the worldview. Therefore, it is very important to study this concept as well as possible and apply the acquired knowledge in practice!

It is important to be fully aware of the ideological ideas that play a key role in the formation of worldviews and their essence. Therefore, in the process of acquainting students with the essence of education in educational institutions, in particular, the basics of social sciences, humanities and natural sciences, national independence is recognized as the main criterion in the social life of the Republic of Uzbekistan. It is a pedagogically effective way to give detailed information about the views put forward in the context of ideas and ideology, to form a certain attitude of students towards them. One goes through different stages in one's life. Personality formation takes place in an environment of constant research and doubt, contradiction and truth. If a person is really interested in his own development and wants to reach the highest level of knowledge, he should develop a personal life position based on his personal worldview. The role of art and national values in shaping the worldview of the younger generation is invaluable. Our national values protect young people from all evils, encourage them to do good deeds, be conscientious, vigilant, strong-willed, soundminded, physically strong, beneficial to society, creative, responsible for the protection of the family, neighborhood, homeland, the country. encourages perfection as a person who performs the uliyya perfectly.

Every nation has many legends and myths about its historical past. They imaginatively reflect the social life, way of life and thinking, social, economic, political and cultural-spiritual relations of this people, who fight against evil forces in the form of legendary heroes. Such legends and myths were originally folklore. in his specimens, and later finds expression in the peculiar literary and artistic works of the developed nations with the advent of writing.

So, along with modern education of the younger generation, educating them in the spirit of universal and national values, high human qualities, reliable protection of their minds and hearts from ideological and spiritual threats, the formation of an active scientific and spiritual worldview in them we pedagogically educators should be in our constant focus.

\section{References:}

1. On the Strategy of Actions for the Further Development of the Republic of Uzbekistan // People's Speech, February 8, 2017, №28 (6722). - B. 1-2.

2. Davronov $\mathrm{Z}$ and others. Philosophy. Textbook. T., 2019. 
3. Komilov N. Sufism. T., 2001.

4. Yuldoshev S. Ancient philosophy. T., 1999.

5. Mahmudov M. Farobi and Aristotle's Poetics. Journal of World Literature, 2011, issue 3.

6. Farobi. A city of noble people. T., 1993. 